\title{
PENGARUH MODEL PEMBELAJARAN KONSTRUKTIVIS 5E TERHADAP HASIL BELAJAR DI SMA LAKSAMANA MARTADINATA
}

\author{
Nazila Ramadhani \\ Jurusan Pendidikan Fisika Universitas Negeri Medan
}

\begin{abstract}
Abstrak. Penelitian ini bertujuan untuk mengetahui pengaruh model pembelajaran konstruktivis 5E terhadap hasil belajar siswa semester ganjil pada materi pokok Medan Magnet di Kelas XII SMA Laksamana Martadinata T.P 2011/2012. Jenis penelitian ini adalah quasi eksperimen. Populasi dalam penelitian adalah seluruh siswa kelas XII Semester Ganjil SMA Laksamana Martadinata yang terdiri dari 3 kelas. Pengambilan sampel dilakukan dengan cara cluster random sampling dengan mengambil 2 kelas dari kelas XII secara acak yaitu kelas XII IPA 1 sebagai kelas eksperimen dan kelas XII IPA 3 sebagai kelas kontrol. Hasil penelitian berdasarkan analisis uji-t dua pihak diperoleh $t_{\text {hitung }}=4,29$ sedangkan untuk $t_{\text {tabel }}=1,669$ sehingga $t_{\text {hitung }}>t_{\text {tabel }}$. Ini berarti Ha diterima, sehingga dapat disimpulkan ada pengaruh yang signifikan penerapan model pembelajaran konstruktivis 5E terhadap hasil belajar siswa pada materi pokok Medan Magnet di kelas XII semester ganjil SMA Laksamana Martadinata T.P 2011/2012.
\end{abstract}

Kata kunci: model pembelajaran, konstruktivis, 5E, hasil belajar

\section{Pendahuluan}

Pada saat ini pendidikan di Indonesia belum mampu memberikan hasil yang maksimal dan mutu pendidikan yang masih rendah. Hal ini dapat dilihat dari hasil studi tentang kualitas pendidikan yang dilakukan oleh Political And Economic Risk Consultancy (PERC) yang dinyatakan dalam laman website bahwa kualitas pendidikan di Indonesia berada pada posisi peringkat terendah di antara 12 negara di Asia (Media Indonesia, 2005). Penurunan prestasi siswa ini terlihat dari hasil belajar siswa saat ini, khususnya di Sumatera Utara tampak dari hasil Ujian Nasional tingkat SMA tahun 2010 yaitu dari 186.845 peserta Ujian Nasional sebanyak 9.844 atau 5,26 persen dinyatakan tidak lulus. Dari jumlah sebanyak 1.940 di antaranya siswa Kota Medan. Persentase kelulusan tahun ini menurun dibandingkan tahun lalu yang mencapai 98\%. Sementara tahun ini hanya $94,74 \%$ atau banyak siswa yang tidak lulus meningkat.
Penyebab lain yang lebih univesal masih rendahnya mutu pendidikan IPA, secara umum diterima para pendidik adalah adanya salah konsep pada diri siswa. Salah satu faktor penting yang dapat mempengaruhi belajar anak adalah apa yang telah diketahui anak. Prakonsepsi yang pada umumnya bersifat salah konsep secara terus menerus dapat mengganggu pembentukan konsepsi ilmiah. Ausebel mengemukakan bahwa pengajaran yang tidak memperhatikan konsepsi awal siswa akan menyebabkan salah konsep siswa menjadi lebih kompleks dan stabil. Keadaan tersebut akan mengakibatkan terjadinya kesulitan belajar dan akhirnya bermuara pada rendahnya hasil belajar siswa.

Belajar dipandang sebagai perubahan konsepsi siswa yaitu konsepsi yang pada mulanya bersifat salah konsep menjadi konsepsi ilmiah. Di sisi lain, mengajar merupakan proses negosiasi makna. Dalam menjalankan fungsinya sebagai fasilitator pembelajaran, pada saat munculnya salah konsep, guru menyajikan 
konflik kognitif sehingga terjadi ketidakseimbangan (disekuilibrasi) pada diri siswa.

Kendala yang dihadapi saat ini, khususnya dalam pembelajaran Fisika, adalah cara guru mengajar jarang menggunakan cara yang seharusnya Fisika diajarkan. Berdasarkan hasil penelitian yang dilakukan oleh Maloney dalam Raduta (2008) menunjukkan bahwa 60\% dari siswa mengatakan bahwa jalur/garis perpindahan muatan pada sebuah medan magnet selalu berbentuk lingkaran. Hal ini merupakan pembuktian bahwa guru pun dapat mengajarkan suatu materi pelajaran yang miskonsepsi. Salah satu alasan para guru adalah sangat sulit mengeksplorasi pengetahuan awal siswa. Para guru cenderung merancang dan mengimplementasikan pembelajaran dengan pola mengajar secara linear.

Berdasarkan latar belakang masalah di atas maka dapat diidentifikasi masalah, yaitu (1) Hasil belajar Fisika yang diperoleh siswa masih belum memenuhi Kriteria Ketuntasan Minimal (KKM) yang diharapkan. (2) Kurangnya pemahaman konsep siswa dalam mempelajari Fisika khususnya materi pokok medan magnet. (3) Guru belum lazim menerapkan model pembelajaran konstruktivis 5E dalam rangka meningkatkan hasil belajar siswa. Permasalahan ini dibatasi pada (1) Model pembelajaran yang digunakan adalah model pembelajaran Kontruktivis 5E. (2) Objek yang diteliti adalah siswa kelas kelas XII Semester Ganjil T.P 2011/2012. (3) Materi pokok Medan Magnet pada kelas XII Semester Ganjil T.P 2011/2012.

Dari latar belakang, identifikasi dan batasan masalah, rumusan masalah penelitian ini adalah (1) Bagaimana aktivitas belajar siswa yang diberikan pembelajaran dengan menggunakan model pembelajaran konstruktivis $5 \mathrm{E}$ dan konvensional pada materi pokok Medan Magnet di kelas XII Semester Ganjil di SMA Laksamana Martadinata T.P 2011/2012. (2) Bagaimana hasil belajar siswa yang diberi pembelajaran dengan menggunakan model pembelajaran kontruktivis $5 \mathrm{E}$ pada materi pokok Medan Magnet di kelas XII Semester
Ganjil di SMA Laksamana Martadinata T.P 2011/2012. (3) Bagaimana hasil belajar siswa yang diberi pembelajaran dengan menggunakan model pembelajaran konvesional pada materi pokok Medan Magnet di kelas XII Semester Ganjil di SMA Laksamana Martadinata T.P. 2011/2012. (4) Bagaimanakah perbedaan hasil belajar siswa yang diberikan pembelajaran dengan menggunakan model pembelajaran konvensional dan konstruktivis 5E pada materi pokok medan magnet di kelas XII Semester Ganjil di SMA Laksamana Martadinata T.P 2011/2012. Sedangkan tujuannya adalah untuk (1) mengetahui hasil belajar siswa dengan menggunakan model pembelajaran kontruktivis 5E pada materi pokok Medan Magnet di kelas XII Semester Ganjil di SMA Laksamana Martadinata T.P 2011/2012. (2) Mengetahui hasil belajar siswa dengan menggunakan model pembelajaran konvensional pada materi pokok Medan Magnet di kelas XII Semester Ganjil di SMA Laksamana Martadinata T.P 2011/2012. (3) Mengetahui aktivitas belajar siswa yang diberikan pembelajaran dengan menggunakan model pembelajaran konstruktivis $5 \mathrm{E}$ di kelas XII Semester Ganjil di SMA Laksamana Martadinata T.P 2011/2012. (4) Mengetahui perbedaan hasil belajar siswa yang diberikan pembelajaran dengan menggunakan model pembelajaran konvensional dan konstruktivis 5E pada materi pokok medan magnet di kelas XII Semester Ganjil di SMA Laksamana Martadinata T.P 2011/2012.

\section{Pandangan Konstruktivisme tentang Belajar}

Teori konstruktivisme menyatakan bahwa dalam proses pembelajaran, pebelajarlah yang harus mendapatkan penekanan. Merekalah yang harus aktif mengembangkan pengetahuan mereka, bukan pembelajar atau orang lain. Mereka yang harus bertanggung jawab terhadap hasil belajarnya. Penekanan belajar siswa secara aktif ini perlu dikembangkan. Kreativitas dan keaktifan siswa akan membantu mereka untuk berdiri sendiri dalam kehidupan kognitif siswa. Belajar lebih diarahkan pada experimental learning, yaitu merupakan adaptasi 
kemanusiaan berdasarkan pengalaman konkrit di laboratorium, diskusi dengan teman sekelas, yang kemudian dielaborasi dan dijadikan ide dan pengembangan konsep baru.

Philosofi konstruktivisme menekankan pada pembelajaran yang berpusat pada siswa (student-centered) yang memberikan ruang seluas-luasnya bagi siswa untuk mengkonstruksi pengetahuan mereka secara mandiri sesuai dengan pengalaman, kemampuan dan tingkat perkembangan individual siswa, baik perkembangan kognitif, afektif maupun psikomotorik. Konstruktivisme merupakan landasan berpikir, bahwa pengetahuan dibangun oleh manusia sedikit demi sedikit yang hasilnya diperluas melalui konteks yang terbatas. Pengetahuan bukanlah seperangkat fakta-fakta, konsep, atau kaidah yang siap untuk diambil dan diingat. Manusialah yang harus mengkonstruksinya dan memberi makna melalui pengalaman nyata (Darma, 2007).

\section{Hasil Belajar}

Hasil dapat diartikan sebagai sesuatu yang diadakan oleh usaha. Dari pengertian tersebut, maka dapat diambil pengertian tentang hasil belajar yaitu usaha-usaha yang dilakukan seseorang melalui perbuatan belajar, sehingga memperoleh hasil dalam bentuk tingkah laku yang baru. Gagne dalam Ainnurahman (2009) menyimpulkan ada lima macam hasil belajar, yaitu: (1) Keterampilan intelektual, atau pengetahuan prosedural yang mencakup belajar konsep, prinsip, dan pemecahan masalah yang diperoleh melalui penyajian materi di sekolah. (2) Strategi kognitif, yaitu kemampuan untuk memecahkan masalah-masalah baru dengan jalan mengatur proses internal masing-masing individu dalam memperhatikan, belajar, mengingat, dan berpikir (3) Informasi verbal, yaitu kemampuan untuk mendeskripsikan sesuatu dengan kata-kata dengan jalan mengatur informasi-informasi yang relevan. (4) Keterampilan motorik, yaitu kemampuan untuk melaksanakan dan mengkordinasi gerakan-gerakan yang berhubungan dengan otot. (5) Sikap, yaitu sesuatu kemampuan internal yang mempeng- aruhi tingkah laku seseorang yang didasari oleh emosi, kepercayaan-kepercayaan serta faktor intelektual.

\section{Model Pembelajaran}

Model pembelajaran adalah suatu perencanaan atau suatu pola yang digunakan sebagai pedoman dalam merencanakan pembelajaran di kelas atau pembelajaran dalam tutorial dan untuk menentukan perangkat-perangkat pembelajaran termasuk didalamnya buku-buku, film, komputer, kurikulum dan lain-lain (Trianto, 2007). Joyce dalam Trianto (2007) menyatakan bahwa setiap model pembelajaran mengarahkan kita ke dalam mendesain pembelajaran untuk membantu siswa sedemikian rupa sehingga tujuan pembelajaran tercapai.

\section{Model Pembelajaran Konstruktivis 5E (Engane, Explore, Explain, Elaborate and Evaluate)}

Model 5E ini merupakan kelanjutan dari model siklus pembelajaran Atkin Karplus yang diusulkan awal tahun 1960 dan yang kemudian digunakan oleh SCSI (Science Curriculum Improvement Study) (Bybee et.al, 2006). Model pembelajaran SCSI (model Atkin dan Karplus) terdiri dari tiga fase yaitu exploration, invention, dan discovery yang kemudian dimodifikasi menjadi exploration, term introduction, and concept application. Dalam model 5E, model SCSI tersebut ditambah dengan dua fase yaitu engagement di awal serta fase evaluation di akhir.

Sejak akhir tahun 1980an, BSCS (Brain, Mind, Experience, and School) telah menggunakan salah satu model pembelajaran secara ekstensif dalam pengembangan kurikulum baru bahan dan pengalaman pengembangan profesional. Model ini biasanya disebut sebagai BSCS 5E Instructional Model, atau 5E, dan terdiri dari tahapan sebagai berikut: keterlibatan, eksplorasi, penjelasan, elaborasi, dan evaluasi. Setiap tahap tertentu memiliki fungsi dan berkontribusi terhadap instruksi koheren guru dan perumusan pembelajar dari pemahaman yang lebih baik bagi pengetahuan ilmiah dan 
teknologi, sikap, dan keterampilan (Bybee and Taylor, 2006).

Adapun fase-fase pada model pembelajaran konstruktivis 5E ini adalah Engage (keterlibatan), Exploration (eksplorasi), Explain (penjelasan), Elaborate (pengeneralisasian konsep), dan Evaluate (mengevaluasi).

\section{Metode Penelitian}

Penelitian dilaksanakan di kelas XII SMA Laksamana Marthadinata Medan. Waktu penelitian akan dilaksanakan pada semester ganjil T.P 2011/2012. Populasi dalam penelitian adalah siswa kelas XII IPA SMA Laksamana Marthadinata T.P 2011/2012. Sampel dalam penelitian ini diambil dengan teknik pengambilan sampel acak berkelompok (cluster random sampling). Sampel yang diambil sebanyak dua kelas XII pada SMA Laksamana Martadinarta Medan.

Penelitian ini termasuk jenis penelitian quasi eksperimen yaitu merupakan penelitian yang dimaksudkan untuk mengetahui ada tidaknya akibat dari sesuatu yang dikenakan pada subjek yaitu siswa.

Bila data penelitian berdistribusi normal dan homogen maka untuk menguji hipotesis menggunakan uji beda dengan rumus:

$$
\mathrm{t}_{\text {hitung }}=\frac{\overline{X_{1}}-\overline{X_{2}}}{S \sqrt{\left(\frac{1}{n_{2}}\right)+\left(\frac{1}{n_{2}}\right)}}(\text { Sudjana, 2002) }
$$

Dimana $S$ adalah varians gabungan yang dihitung dengan rumus

$$
\mathrm{S}^{2}=\frac{\left(n_{1}-1\right) S_{1}^{2}+\left(n_{2}-1\right) S_{2}^{2}}{n_{1}+n_{2}-2}
$$

Dengan $\mathrm{t}=$ distribusi $\mathrm{t} ; \overline{x_{1}}=$ nilai rata-rata kelas eksperimen; $\overline{x_{2}}=$ nilai rata-rata kelas kontrol; $\mathrm{n}_{1}=$ ukuran kelas eksperimen; $\mathrm{n}_{2}=$ ukuran kelas kontrol; $\mathrm{S}_{1}^{2}=$ varians kelas eksperimen; $\mathrm{S}_{2}^{2}=$ varians kelas kontrol. Kriteria pengujian adalah terima Ho jika $-t_{1-1 / 2 \alpha}<t<t_{1-1 / 2 \alpha}$ dimana $t_{1}-1 / 2 \alpha$ didapat dari daftar distribusi $\mathrm{t}$ dengan $\mathrm{dk}=\left(n_{1}+n_{2}-2\right)$ dan peluang
$(1-1 / 2 \alpha)$ dan $\alpha=0,05$. Untuk harga $\mathrm{t}$ lainnya Ho ditolak.

\section{Hasil Penelitian dan Pembahasan Hasil Penelitian}

Sebelum memulai pembelajaran dengan model pembelajaran konstruktivis 5E dan model pembelajaran konvensional maka terlebih dahulu peneliti memberikan pretes yang bertujuan untuk mengetahui kemampuan awal siswa. Dari tes yang telah dilakukan, diperoleh data pretes untuk kelas eksperimen dan kelas kontrol. Pada kelas eksperimen nilai tertinggi 53,3 dan terendah 20,0 dengan nilai rata-rata 33,5 dan standar deviasi 10,3. Sedangkan pada kelas kontrol nilai tertinggi 53,3 dan terendah 13,3 dengan nilai rata-rata 33,0 dan standar deviasi 11,3 .

Setelah dilakukan pretes, peneliti melaksanakan perlakuan pembelajaran yang berbeda terahadap kedua kelas. Diakhir kegiatan pembelajaran, dilaksanakan postes yang hasilnya untuk kelas eksperimen nilai tertinggi 93,3 dan terendah 26,7 dengan nilai rata-rata 76,5 dan standar deviasi 9,2. Pada kelas kontrol diperoleh nilai tertinggi 73,3 dan nilai terendah 26,7 dengan nilai rata-rata 52,2 dan standar deviasi 14,9.

Kemudian dilakukan uji normalitas data penelitian dilakukan dengan menggunakan uji Liliefors. Uji normalitas dimaksudkan untuk mengetahui apakah data kedua sampel berdistribusi normal atau tidak. Dapat diperoleh bahwa nilai pretes kedua kelompok sampel memiliki data yang normal atau $\mathrm{L}_{\text {hitung }}<\mathrm{L}_{\text {Tabel }}$ (kelas eksperimen: $0,1454<0,1497$ ) dan ( kelas kontrol: $0,1123<0,1497)$ pada taraf signifikan 0,05 dan $\mathrm{N}_{\text {eksperimen }}=35, \mathrm{~N}_{\text {kontrol }}=35$.

Uji homogenitas data penelitian dilakukan dengan menggunakan uji F. Uji homogenitas data bertujuan untuk mengetahui apakah kedua sampel berasal dari populasi yang homogen atau tidak. Hasil uji homogenitas pretes diperoleh nilai $F_{\text {hitung }}=1,219$. Pada taraf signifikan 0,05 diperoleh harga $F_{\text {Tabel }}=1,732$. Karena $\mathrm{F}_{\text {hitung }}<\mathrm{F}_{\text {Tabel }}$ maka data pretes kedua sampel homogen yang berarti bahwa data yang 
diperoleh dapat mewakili seluruh populasi yang ada.

Pengujian hipotesis ditentukan dengan melihat perbedaan hasil belajar siswa kelas eksperimen. Nilai rata-rata pretes kelas eksperimen adalah 33,5 dan kelas kontrol adalah 33,0. Dari Hasil perhitungan diperoleh $t_{\text {hitung }}=0,194$ dan $t_{\text {tabel }}$ untuk $\alpha=0,05$ adalah 1,997. Karena $\mathrm{t}_{\text {hitung }}<\mathrm{t}_{\text {tabel }}$ dapat dinyatakan bahwa tidak ada perbedaan kemampuan awal antara kelas eksperimen dan kelas kontrol.

Nilai rata-rata postes kelas eksperimen adalah 76,5 dan kelas kontrol adalah 52,2. Hasil pengujian hipotesis pada taraf signifikan $\alpha=$ 0,05 dan $\mathrm{dk}=68$, untuk pengujian postes diperoleh $t_{\text {hitung }}=4,29$ sedangkan $t_{\text {Tabel }}=1,669$. Kriteria pengujian adalah terima $\mathrm{H}_{0}$ jika $-t_{1-1 / 2 \alpha}<t<t_{1-1 / 2 \alpha}=-1,669<\mathrm{t}_{\text {hitumg }}<1,669$, serta tolak $\mathrm{H}_{\mathrm{o}}$ jika $\mathrm{t}$ memiliki harga yang lain. Karena harga $t_{\text {hitung }}=4,29$, maka $\mathrm{H}_{\mathrm{a}}$ diterima dan menolak $\mathrm{H}_{\mathrm{o}}$ yang berarti terdapat perbedaan hasil belajar siswa yang menggunakan model pembelajaran konstruktivis 5E dengan model pembelajaran konvensional pada materi pokok Medan Magnet di kelas XII Semester I di SMA Laksamana Martadinata T.P 2011/2012.

Untuk mengetahui aktivitas yang dilakukan siswa selama proses pembelajaran maka pada saat pembelajaran berlangsung dilakukan observasi yang dilakukan selama kegiatan belajar mengajar berlangsung oleh 2 orang pengamat yang telah dilengkapi dengan lembar observasi. Adapun jenis aktivitas yang diamati adalah (1) memberikan pertanyaan, (2) memberikan tanggapan, (3) memeberikan jawaban, dan (4) menyampaikan ide, (5) membuat kesimpulan, untuk pertemuan 1, begitu juga untuk pertemuan ke-2 dan ke-3. Aspek-aspek tersebut diberi skor 1 sampai 3 dengan berpedoman pada penskoran observasi aktivitas siswa.

Berdasarkan data hasil observasi aktivitas belajar siswa selama menggunakan model pembelajaran konstruktivis $5 \mathrm{E}$ menunjukkan bahwa pada pertemuan 1 diperoleh nilai ratarata aktivitas siswa 67,12 dalam kategori aktif, pada pertemuan 2 diperoleh nilai rata-rata aktivitas siswa 70,8 dalam kategori aktif dan pada pertemuan 3 diperoleh nilai rata-rata aktivitas siswa 72,06 dalam kategori aktif. Dari ketiga pertemuan diperoleh rata-rata aktivitas belajar siswa 74,4 dalam kategori aktif.

\section{Pembahasan Penelitian}

Peneliti melakukan proses kegiatan belajar mengajar di kelas XII IPA 1 sebagai kelas eksperimen dengan menggunakan model pembelajaran konstruktivis 5E. Sebelum melakukan pembelajaran, peneliti menyiapkan alat dan bahan yang akan diperlukan selama proses pembelajaran berlangsung. Kegiatan belajar mengajar dengan menggunakan model pembelajaran konstruktivis 5E melalui lima tahapan pembelajaran yaitu Engage, Explore, Explain, Elaborate dan Evaluate.

Tahap Engage, yaitu fase keterlibatan (engage) yang dilakukan untuk mendapatkan perhatian siswa, membuat siswa berpikir tentang topik pelajaran yang akan dipelajari, menstimulasi kemampuan berpikir siswa dan mengetahui pengetahuan awal siswa.

Tahap Explore, yaitu fase yang memungkinkan dilakukannya observasi, pengambilan data, menggambar grafik atau mengembangkan hipotesis. Peneliti membentuk beberapa siswa menjadi beberapa kelompok belajar dimana siswa dapat melakukan praktikum, mengembangkan pemikiran siswa sesuai dengan apa yang diketahui dan kemudian membuat hipotesis dan kesimpulan dari praktikum yang dilakukan.

Tahap Explain yaitu fase dimana siswa menjelaskan dan mempresentasikan hasil praktikum yang telah diamati dengan bahasa siswa sendiri.

Tahap Elaborate yaitu fase penstransferan pengetahuan dari satu konsep ke konsep yang lain. Pada fase ini peneliti mengingatkan dan menerapkan konsep pada situasi yang baru dan dapat mengubah pengetahuan awal siswa menjadipengetahuan yang koheren dan sesuai dengan konsep Fisika.

Tahap Evaluate yaitu fase evaluasi yang dilakuakan guru untuk melihat kemampuan siswa. Peneliti melakukan evaluasi dengan 
memberikan soal latihan sebanyak 3 soal yang berhubungan dengan materi pelajaran.

Secara teoritis hasil belajar dengan menggunakan model pembelajaran konstruktivis $5 \mathrm{E}$ lebih baik karena memiliki lima tahap pembelajaran dimana setiap tahap tertentu memiliki fungsi dan berkontribusi terhadap instruksi koheren guru dan perumusan pembelajar dari pemahaman yang lebih baik bagi pengetahuan ilmiah dan teknologi, sikap, dan keterampilan.

Berdasarkan hasil tersebut menunjukkan bahwa rata-rata hasil belajar siswa setelah diberi pembelajaran dengan menggunakan model pembelajaran konstruktivis 5E lebih tinggi dibandingkan hasil belajar siswa yang diberikan pembelajaran dengan menggunakan model pembelajaran konvensional pada materi pokok medan magnet semester ganjil di SMA Laksamana Martadinata. Hal ini menunjukkan bahwa ada pengaruh yang diberikan pembelajaran dengan menggunakan model pembelajaran konstruktivis $5 \mathrm{E}$ terhadap hasil belajar siswa XII Semester Ganjil SMA Laksaman Martadinata T.P 2011/2012.

\section{Simpulan}

Kesimpulan dalam penelitian ini adalah (1) Aktivitas siswa selama mengikuti pembelajaran dengan menggunakan model pembelajaran konstruktivis $5 \mathrm{E}$ diperoleh rata-rata skor aktivitas siswa mencapai 74,4 dengan kategori aktif sedangkan dengan menggunakan model pembelajaran konvensional diperoleh rata-rata skor aktivitas siswa mencapai 61,5 dengan kategori cukup aktif. (2) Hasil belajar siswa yang diberi pembelajaran dengan model pembelajaran konstruktivis 5E pada materi pokok Medan Magnet di kelas XII SMA Laksamana Martadinata T.P.2011/2012 sebelum diberikan perlakuan rata-rata pretes sebesar 33,5 dan setelah diberikan perlakuan rata-rata postes siswa sebesar 66,3. (3) Hasil belajar siswa yang diberikan dengan model pembelajaran konvensional pada materi pokok Medan Magnet di kelas XII SMA Laksamana Martadinata T.P 2011/2012 sebelum diberikan perlakuan ratarata pretes sebesar 33,0 dan setelah diberikan perlakuan rata-rata postes siswa sebesar 52,2. (4) Terdapat perbedaan akibat pengaruh penerapan model pembelajaran konstruktivis $5 \mathrm{E}$ dan konvensional terhadap hasil belajar siswapada materi pokok Medan Magnet di kelas XII SMA Laksamana Martadinata T.P.2011/2012 yaitu sebesar $21,26 \%$.

\section{Daftar Pustaka}

Ainurrahman. 2009. Belajar dan Pembelajaran. Bandung: Alfabeta.

Bybee, R. W., taylor, J. A., Gardner, A., Van Scotter, P. Powell, J. C., Webstrook, A., \& Landes, N. (2006). The BSCS 5E instructional model: Origins and effectiveness. Dapat diakses pada http://science. education.nih.gov/housefreps.nsf/

Cipta Science Team. 1999. Panduan dan Pembahasan Lengkap Ebtanas Fisika. Jakarta: Penerbit Yustadi.

Darma, K. 2007. Pengaruh model pembelajaran konstruktivisme terhadap prestasi belajar matematika terapan pada mahasiswa Politeknik Negeri Bali. Jurnal Pendidikan dan Kebudayaan No.70.

Raduta, C. 2008. General Students' Misconceptions related to lectricity and Magnetism. Ohio: The Ohio State University.

Sudjana. 2005. Metoda Statistika. Bandung: Tarsito.

The Science Teacher. 2003. Expanding the 5E Model. Arlington: the National Science Teachers Association.

http://www.indonesiamedia.com/2005/07/mid/o pini/pelajar.htm). 